\title{
Developing Learning Material Book of Statistics Based on Statistical Application (SPSS) and Task Portfolio
}

\author{
Joko Suharianto ${ }^{1, *}$, Muhammad Yusuf ${ }^{1}$, Eko Wahyu Nugrahadi ${ }^{1}$, \\ Choms Gary G.T. Sibarani ${ }^{1}$
}

\author{
${ }^{1}$ Faculty of Economic, Universitas Negeri Medan \\ ${ }^{*}$ Corresponding Author. Email: djoko@unimed.ac.id
}

\begin{abstract}
This research is a research of development to develop and create a textbook of statistics based on SPSS application book had signed to improve students' ability to master statistics both manually and through SPSS. This employed the Research and Development method for developing and validating product of research with ten stages are: 1) Potency and Problem, 2) Data Collecting, 3) Product Design, Validation, 5) Design Revision, 6) Small group product trial, 7) First product revision, 8) Usage test, 9) Second revision and 10) Mass production. This book's making only to reach the seventh step, the first product revision Data were analyzed using descriptive statistics, Cochran's Q test, and paired sample t-test. The analysis result discussion of this research showed that the statistic textbook-based SPSS application was valid, effective, and fit with applicable criteria.
\end{abstract}

Keywords: Statistics, SPSS Application, Task Portfolio

\section{INTRODUCTION}

The role of statistics is to plan, collect, analyze, interpret, and present data to produce significant decisions for developing science and technology. Its function applies statistics widely applied in various scientific disciplines, natural sciences, social sciences, and humanities, which develop logical and scientific ways of thinking. According [1], statistics are knowledge related to collecting data, processing or analyzing them, and drawing conclusions based on data sets and analyzing them.

Statistics is a material used in various fields. However, students are still not top interested in learning the material. These were explained by [2], that one of the causes of students being less interested in statistics is that Statistics still taught theoretically and less connected to the real world. Therefore, the students do not know the application in each of these materials. In addition to statistical learning, traditional lecture formats and knowledge transfer models remain the mainstay method. This further decreases the motivation of students to study statistics.

Further was explained by [3] that in learning knowledge, it should be connected with the real world and describes how the experience is applied. Without this, it can cause a lack of learning motivation. This research has an impact on their learning achievement, especially on problem-solving abilities. One of the efforts to motivate students is the contextual teaching and evaluation of the learning process.

According to [3], many students have difficulty analyzing statistical data so far. Students commonly experienced problems and mistakes, including the tests used in data analysis, uncertainty in calculating data analysis, and accuracy of solutions that result in conclusion drawing. The use of information technology that is increasingly developing, especially computer software development, can help accelerate and facilitate the understanding and analysis of statistical data processes to improve students' competence in Statistics lectures.

The above problems are in line with the development of the concept of the Industrial Revolution era 4.0, which is currently developing. Therefore, there needs to be a new orientation to the idea of learning in the world of education. [5] explained that education and work's relevance need to be adjusted to the development of the era and science and technology while still paying attention to humanity's aspects. The graduate was preparing to be competitive; the curriculum needs a new 
orientation. The reason is not enough only on old literacy (reading, writing, \& mathematics). These will be the essential capital to take part in the community. However, it also equips students with three new literacies, namely data literacy (the ability to read, analyze, and use information (Big Data) in the digital world), technology literacy (understanding how machines, technology applications), and human literacy work (humanities, communication, and design).

They were responding in the industrial revolution era 4.0. Then there needs to be a strengthening of technological literacy to improve student competencies in understanding the workings of statistical applications, one of which is the most familiar, SPSS. As a result of learning, students are hopefully expected to have the skills in processing and analyzing data, having knowledge and logical understanding of a problem based on factual data, able to use statistical software (statistical software) as a computational tool, and able to read and interpret computational results correctly with a fast time and with accurate results.

The problem is that books used in statistical courses are still focusing on theory and manual calculations. Of course, it is not relevant in improving technological literacy competencies. The lecturer team previously did a statistical module, but the research and development $(\mathrm{RnD})$ process has not been passed and has not provided information about the use of relevant statistical applications. Therefore, the statistical course's lecture process is regarded as necessary to develop a teaching material that can help students understand statistical material based on SPSS applications. Not only that, but the concept of this teaching material will also good with a task portfolio, the concept format of six tasks of KKNI in the form of routine assignments, journal reviews, critical book report (CBR), mini-research, project and engineering ideas adopted by the State University of Medan. This teaching material is designing for students in such a way as to make it easier for lecturers and homogenize information to students about the concept of task portfolio.

Based on this background, research was conducted on developing textbooks to improve student statistics learning outcomes. The main objective to be achieved in this study was the production of a statistical application based on statistical books (SPSS) with a portfolio assessment approach of 6 KKNI tasks. Textbooks were designed to connect the knowledge gained with real cases faced in life to provide accurate solutions and communicate them appropriately

\section{THEORETICAL FRAMEWORK}

Teaching materials are a set of systematically arranged materials, both written and unwritten, so that an environment and atmosphere allow students to learn is created [6]. The ultimate goal of all efforts in education is to increase student success. Therefore, all attention is focused on improving the efficiency of the learning process. Competent lecturers should be evaluating learning outcomes in the context of learning objectives and adapt learning according to the results of the assessment carried out [7].

Students' learning outcomes are influenced by several learning conditions, namely, internal and external conditions. Internal factors are factors that exist in themselves called individual elements. These factors are maturity or growth, intelligence, practice and replication, motivation, personality traits. External factors that live outside of these factors include family factors, lecturers, facilities and infrastructure, and the environment [8]. The development of applied statistical teaching materials combines manual statistical calculations and statistical applications with SPSS. The result of teaching materials is part of the external factors expected to improve students' learning outcomes.

The development of ideal teaching materials can facilitate students' acquiring knowledge, encourage lecturers to teach, assign assignments, and evaluate students' learning outcomes. For this reason, the development of teaching materials will also be adapted to the curriculum design adopted in Unimed, namely the KKNI, with six specific tasks, namely routine assignments, journal reviews, critical book reports, miniresearch, projects, and ideas engineering. So, in this case, the development of statistical teaching materials will also adopt the concept of evaluating the portfolio with the idea of 6 tasks into preparing the statistical textbook. Of course, it will homogenize information, knowledge, and conceptual schemes; therefore, it will be easier for the lecturers to teach.

\section{RESEARCH METHOD}

This research is a Research and Development research on developing the statistical textbook based on statistical application (SPSS) assignments to improve student economic statistics learning outcomes. This research was conducted at the Economic Education Study Program of the State University of Medan. This research employed research and development methods. According to [9], development research aims to develop and validate research products. There are ten steps in conducting Research and Development method, they are: 1) Potency and Problem, 2) Data Collecting, 3) Product Design, 4) Design Validation, 5) Design Revision, 6) Small group product trial, 7) first product revision, 8) usage test, 9) second product revision and 10) mass production [10].

In this study, the steps used only reached the 7 th stage, namely product revision II, namely the availability of a limited draft revised teaching material in the form of 
a revision test of the textbook test results in a small class sample to determine the effectiveness and practicality of textbooks.

\section{RESULTS AND DISCUSSION}

The development of teaching materials had passed a series of research and development with the following steps:

a. Potency and Problems, the availability of studies on the potency and problems of developing economic statistics teaching materials.

At this stage, the background of the development of Statistics Book teaching materials commonly used and discussed by students. Students of education programs are ideally focused on applied statistics on education that can be directly applied to their thesis research preparation. The results of the evaluation to students turned out to have several obstacles, including the following:

1) Some material taught cannot be directly used in statistical applications, especially in education, for example, index numbers, seasonal index and cyclical movements, and periodical data analysis. While there was material needed but not presented, namely understanding quantitative and qualitative research approaches, parametric statistical prerequisite tests: normality and homogeneity, different test two parameters, and analysis of variance.

2) The material taught was still based on manual or excel calculations only. Meanwhile, to respond to the Industrial Revolution 4.0 era, it is necessary to adapt the technology by completing the manual calculation material and also using the statistical analysis application, in this case, is SPSS.

b. Data Collecting, namely the availability of information that can be used for planning the preparation for teaching material in the Economic Statistics in this study, is:

1) Document of RPS standardization of Economic Statistics course

2) Concept document of six tasks of KKNI of Economic Statistics course

3) Document of assessment instrument of the learning outcomes of Economic Statistics

Based on the result of the discussion, it can be formulated that the material of statistics can be divided into nine chapters, as follow:

Chapter 1: Introduction

Chapter 2: Process of research, Variable and Quantitative Research Paradigm
Chapter 3: Collecting and Presenting Data

Chapter 4: Centralized Trend Measures and Spread

Chapter 5: Data Analysis and Research Hypothesis

Chapter 6: Prerequisite Test for Parametric Analysis: Normality Test, and Homogeneity

Chapter7: Difference Test for Two Average Parameters

Chapter 8: Correlation Analysis (Simple and Multiple) Chapter 9 Regression Analysis (Simple and Multiple)

c. Product Design, the availability of a draft of a statistics book.

At the design stage, textbooks were developed based on competency standards, essential competencies, and indicators of competence in Statistics courses. In this study, a statistical textbook based on the SPSS statistics application was created. Book materials were arranged in 12 Chapters, each of which consists of a description of the subject matter of the learning, case examples following the main material, and completed with examples of case calculations for both the manual and the SPSS application. Question exercises are designed to be evaluated with portfolio-based assessments.

d. Validation of Design, the availability of a document of the validation test result from the validation of the experts for the content.

The textbook that had been compiled at the product design stage is draft 1 , then tested through several steps. The first stage is the validation of books using expert validity assessment.

The validation carried out consisted of two stages, namely, 1) confirmation of the validation sheet questionnaire that was used by the expert team in assessing the module, 2) book validation through a questionnaire given to the expert team after revision. Questionnaire validation was carried out by three validators who are experts in statistics.

The experts who considered the validity of the contents of statistical textbooks based on the SPSS application and task portfolio are (1) Dr. M. KMS. M Amin Fauzi, M.Pd. (Mathematics of Mathematics Education Study Program); (2) Dr. Dede Ruslan, M.Sc. (Lecturer in Statistics for Economic Education Study Program) and (3) Dr. M. Fitri Ramadana, M.Si (Lecturer 
in Statistics for Economic Education Study Program). Following are the results of expert validation regarding module improvements.

Table 1. Details of Review Results from Validators

\begin{tabular}{|c|c|c|}
\hline No & Name & Validation \\
\hline 1 & $\begin{array}{l}\text { Dr. KMS } \\
\text { M. Amin } \\
\text { Fauzi, } \\
\text { M.Pd. }\end{array}$ & $\begin{array}{l}\text { - Design the book to be more } \\
\text { exciting and provide tips } \\
\text { and tricks in making } \\
\text { calculation } \\
\text { interpretation the result. and } \\
\text { - The pictures of SPSS steps } \\
\text { needed to be enlarged to } \\
\text { make it easier to read } \\
\text { - Make the cover of the book } \\
\text { interesting }\end{array}$ \\
\hline 2 & $\begin{array}{l}\text { Dr. Dede } \\
\text { Ruslan, } \\
\text { M.Si. }\end{array}$ & $\begin{array}{l}\text { - Nceded uniformity of the } \\
\text { examples of the exercises } \\
\text { with case relevant to } \\
\text { students' research. } \\
\text { - The pictures needed to be } \\
\text { more colorful to make them } \\
\text { interesting } \\
\text { - Fix the redaction of the } \\
\text { language so it can be easily } \\
\text { understood }\end{array}$ \\
\hline 3 & $\begin{array}{l}\text { Dr. M. } \\
\text { Fitri } \\
\text { Ramadana, } \\
\text { M.Si. }\end{array}$ & $\begin{array}{l}\text { - The purpose of the learning } \\
\text { must be aligned with the } \\
\text { KKNI of Unimed. } \\
\text { - Exercises were not enough. } \\
\text { - The layout of the book } \\
\text { needed to be } \\
\text { more interesting }\end{array}$ \\
\hline
\end{tabular}

Some aspects observed in the textbook can be seen in Table 2. Based on the three expert's consideration of the 16 aspects observed from the 12 chapters received overall assessment.
Table 2. Aspects of Validity of the Content of the Textbook.

\begin{tabular}{|c|c|c|c|c|}
\hline No & Observed Aspects & 1 & 2 & 3 \\
\hline 1 & $\begin{array}{l}\text { Book is under the Curriculum } \\
\text { Syllabus }\end{array}$ & 1 & 1 & 1 \\
\hline 2 & $\begin{array}{l}\text { Books is under the expected essential } \\
\text { competencies }\end{array}$ & 1 & 1 & 1 \\
\hline 3 & $\begin{array}{l}\text { Book is relevant to the material } \\
\text { needed to be learned by the students }\end{array}$ & 1 & 0 & 1 \\
\hline 4 & $\begin{array}{l}\text { The content of the material has the } \\
\text { right and precise concept. }\end{array}$ & 0 & 1 & 1 \\
\hline 5 & The book helps explain the concept & 1 & 1 & 1 \\
\hline 6 & $\begin{array}{l}\text { The book contains exercises example } \\
\text { of manual and SPSS application }\end{array}$ & 1 & 1 & 1 \\
\hline 7 & $\begin{array}{l}\text { The book includes exercises portfolio } \\
\text {-based assessments }\end{array}$ & 1 & 0 & 1 \\
\hline 8 & $\begin{array}{l}\text { Suitability of exercises to learned } \\
\text { material }\end{array}$ & 1 & 1 & 1 \\
\hline 9 & $\begin{array}{l}\text { Suitability of exercise examples and } \\
\text { exercises to the ability which is } \\
\text { expected to be improved }\end{array}$ & 0 & 1 & 1 \\
\hline 10 & $\begin{array}{l}\text { Activities have met the difficulty } \\
\text { level proportion }\end{array}$ & 1 & 1 & 0 \\
\hline 11 & $\begin{array}{l}\text { The language used is already correct } \\
\text { and precise }\end{array}$ & 1 & 1 & 0 \\
\hline 12 & $\begin{array}{l}\text { The language used can be understood } \\
\text { easily }\end{array}$ & 1 & 1 & 1 \\
\hline 13 & $\begin{array}{l}\text { The display and the arrangement of } \\
\text { the book are interesting }\end{array}$ & 1 & 0 & 1 \\
\hline 14 & $\begin{array}{l}\text { The structure of the pictures and the } \\
\text { tables are interesting }\end{array}$ & 0 & 1 & 1 \\
\hline 15 & The size of the font used is clear & 1 & 0 & 1 \\
\hline 16 & $\begin{array}{l}\text { Students can use the book } \\
\text { independently }\end{array}$ & 1 & 1 & 1 \\
\hline
\end{tabular}

From the value data from the validator, then it was performed an analysis using nonparametric statistical analysis using the Q-Cochran test which aimed to determine whether the experts have a judgment in the validity of the content of textbooks with the following calculation results:

Table 3. The Result of the calculation of Cochran's Q Test

Test Statistics

\begin{tabular}{l|r}
\hline N & 16 \\
\hline Cochran's Q & $.667^{\mathrm{a}}$ \\
\hline Df & 2 \\
\hline Asymp. Sig. & .717 \\
\hline
\end{tabular}

a. 1 is treated as a success. 
Based on the table, it was obtained from the Test Statistics table that many members of the sample $(\mathrm{N}=16)$ and value of Cochran's Q or Q value 0.667 , deviate of freedom (df) 2, a and Asymp. Sig.0.717 because Sig $0.717>0.05$, then it can be concluded that in general, all experts had the same considerations regarding the teaching material. Therefore, it can be concluded that the draft of the teaching material was valid.

Table 4. The result of the Calculations of Paired Difference Test.

\begin{tabular}{|c|c|c|c|c|c|c|c|}
\hline \multicolumn{5}{|c|}{ Paired Differences } & \multirow[b]{2}{*}{$\mathrm{T}$} & \multirow[b]{2}{*}{ df } & \multirow[b]{2}{*}{ Sig. } \\
\hline & & $\begin{array}{l}\mathrm{Me} \\
\text { an }\end{array}$ & $\begin{array}{l}\text { Std. } \\
\text { Dev. }\end{array}$ & $\begin{array}{l}\text { Std. } \\
\text { Error } \\
\text { Mean }\end{array}$ & & & \\
\hline $\begin{array}{l}\text { Pair } \\
1\end{array}$ & $\begin{array}{l}\text { Before- } \\
\text { After }\end{array}$ & 19 & 3.94 & 1.24 & 15.2 & 9 & .000 \\
\hline
\end{tabular}

e. Design Revision I (draft2), namely the availability of revision draft of the experts' design validation.

After the experts' validation stage, it was revised the teaching material draft by adjusting the experts' assessment, so that draft 2 of statistics teaching material was created.

Table 5. The Assessment of Readability of the Book on the Limited Sample

\begin{tabular}{|c|c|c|}
\hline No & Indicator & Sum \\
\hline $\mathbf{A}$ & \multicolumn{2}{|l|}{ Variable: The ease of the User (Learnability) } \\
\hline 1 & Guidance in using the teaching material & 43 \\
\hline 2 & $\begin{array}{l}\text { The usage of the language and the sentence } \\
\text { structure is suitable to the students' ability }\end{array}$ & 42 \\
\hline 3 & $\begin{array}{l}\text { It can support the learning process of } \\
\text { individuals or group }\end{array}$ & 45 \\
\hline 4 & $\begin{array}{l}\text { Exercises can help students to understand } \\
\text { the concept }\end{array}$ & 44 \\
\hline B & \multicolumn{2}{|l|}{ Variable: Efficiency } \\
\hline 1 & $\begin{array}{l}\text { Teaching material can help students in } \\
\text { deepening the understanding of the material }\end{array}$ & 45 \\
\hline 2 & $\begin{array}{l}\text { Figures in the teaching material can help } \\
\text { students find concepts }\end{array}$ & 42 \\
\hline 3 & The materials are understandable & 45 \\
\hline 4 & $\begin{array}{l}\text { Tasks in the teaching material can help the } \\
\text { students in understanding concepts }\end{array}$ & 44 \\
\hline 5 & $\begin{array}{l}\text { Teaching material is more practical and can } \\
\text { be adjusted to the ability of the students } \\
\text { without differentiation of SARA (Ethnic, } \\
\text { Religion, Race, Group) }\end{array}$ & 43 \\
\hline 6 & $\begin{array}{l}\text { The attractiveness of the display of the } \\
\text { teaching material motivates students to } \\
\text { learn }\end{array}$ & 45 \\
\hline $\mathbf{C}$ & \multicolumn{2}{|l|}{ Variable: Effectiveness of Time } \\
\hline 1 & $\begin{array}{l}\text { The usage of the teaching material can } \\
\text { make learning time efficient }\end{array}$ & 44 \\
\hline
\end{tabular}

f. Product Testing, namely the limited test document, results in a small class sample, one semester III class, a class that had finished the Statistics course in the previous semester. Experiment design of after-before on the sample of Regression material was conducted in two meetings.

The results of this small group trial with experimental research design before after using a different test of two paired parameters (paired-sample t-test) with the following products:

Based on the table, it was obtained that the value of $t$ is 15,234 the value of Sig < 0,00. Because Sig 0,00< 0,05 , then it can be concluded that there were differences in terms of the learning outcomes in small group sample before and after the treatment of using the teaching material. That means the arranged teaching material gave a more realistic learning outcome than that of the previous book. Next, the result of the readability test on the limited sample, which consisted of ten students, can be seen from the following Table 5 .

Based on the assessment of the book's readability, it can be seen that the ten students had high scores (Score 4 $=$ Agree, Score $5=$ Really Agree) towards all indicators of the book's readability. It means that the statistics teaching material based on SPSS application and task portfolio could be understood easily by the students. The readability result of the teaching material was measured using the Likert scale value's conversion with a range of highest total value until the lowest, $0-50$, as displayed in Table 6.

Table 6. Criteria of Teaching Material's Practically.

\begin{tabular}{|c|c|}
\hline Interval & Criteria \\
\hline $0-10$ & Very Weak \\
\hline $11-20$ & Weak \\
\hline $21-30$ & Enough \\
\hline $31-40$ & Strong \\
\hline $41-50$ & Very Strong \\
\hline
\end{tabular}

Based on the result of the limited sample assessment, it can be concluded that the majority of the indicators were in Very Strong score interval. Therefore, it can be said that the developed book had fulfilled the criteria of readability and practicality.

g. Product Revision II, the availability of the draft revision of teaching material from the results of limited test input.

After going through the product testing phase in a small sample and the readability test to students, revision was carried out according to student input to produce a draft three statistics textbook that was ready to be tested on large group samples.

Based on the questionnaire results, the results showed that most students felt good after using statistical textbooks based on the SPSS application. Students 
already seemed interested in reading a book at the initial meeting because it was provided with a manual and SPSS calculation guide that they did not get before. However, there were some suggestions from students for this book revision, which are the design of books and covers that could be more interesting, and the drawing of the calculation phase with the help of SPSS could be made bigger so that it provides clarity. Also, students are expected to maximize statistical learning results; therefore, it is necessary to have more supportive learning facilities, namely learning in the computer laboratory.

\section{CONCLUSION}

Based on the development of instructional materials, it was produced statistical textbooks designed based on the SPSS application. Statistics teaching materials were made through research and development (R\&D) low based on expert considerations, limited sample tests, and teaching materials' readability. The development of this teaching material was carried out based on Borg and Gall's research and development model. Based on this model, the textbook was developed only in stage 7 , a revision to small sample trials. Furthermore, draft 3 of this statistical book can be used for lectures on Statistics courses at the next large sample's trial stage.

Research and development of the teaching material of Statistics based on SPSS only reached the seventh stage of ten planned locations. Thus, it needs further development and perfection in the steps of the research and development of these teaching materials. The next step is mass sample testing, which tests the teaching material to two classes for one semester with experimental research design and one control class. At the end of the meeting, there will be a test of learning outcomes and questionnaire for testing and an open questionnaire about the statistics teaching material to be revised to create final book revision before it is proposed to be mass-produced.

\section{AUTHORS' CONTRIBUTIONS}

The author has drafted a book to assist students in learning statistics. The results of this study concluded that most students felt good benefits after using the Statistics textbook based on the SPSS application and a portfolio of $6 \mathrm{KKNI}$ assignments. The effectiveness and readability of this book are considered good based on assessing the students' energy and legibility. Based on this model, developed textbooks can be used for Statistics courses. Henceforth, this book's draft will enter the next stage, namely the subsequent large sample trial.

\section{ACKNOWLEDGMENTS}

Researchers would like to thank Universitas Negeri Medan for funding this research activity. Besides, the authors would like to thank the Unimed Community
Service Research Institute, the Community of the Faculty of Economics, the Economic Education Study Program, and the students involved as the research samples.

\section{REFERENCES}

[1] Sudjana. Metode Statistika Edisi Keenam. Bandung: Tarsito. 2005.

[2] Shi.Ning-zhong. Understanding Statistics and Statistiscs Education: A Chinese Perspective. Journal of Statistic Education. 17 (3), 2009. Pp 1-8.

[3] Leibman, Zipora., Integrating Real Life Data Analysis in Teaching Descriptive Statistics: A Constructivist Approach. Journal of Statistic Education.18, (1). 2010.

[4] Hendikawati, Putriaji, dan Arini, Florentina Yuni. Pengembangan Bahan Ajar Statistika Berbantuan TIK dengan Pendekatan Penilaian Protofolio untuk Meningkatkan Komunikasi dan Koneksi Matematis. Jurnal Penelitian Pendidikan. Vol. 33 Nomor 2 Tahun 2016.

[5] Ahmad, Intan. Proses Pembelajaran Digital dalam Era Revolusi Industri 4.0. Direktur Jenderal Pembelajaran dan Kemahasiswaan. Kemenristek Dikti. 2018.

[6] Prastowo, Andi. Panduan Kreatif Membuat Bahan Ajar Inovatif: Menciptakan Metode Pembelajaran yang Menarik dan Menyenangkan. Yogyakarta: Diva Press. 2011.

[7] Santrock, J.W. Educational Psychology Second Edition, terjemahan Tri Wibowo. Jakarta: Kencana Perdana Media Group. 2007.

[8] Thobroni, M. Belajar dan Pembelajaran Teori dan Praktek. Jakarta: Ar Ruzz Media. 2015.

[9] Borg, Walter., \& Gall, M.D. Educational Research: An Introduction ( $4^{\text {th }}$ Ed). New York \& London: Longman. 1983.

[10] Sugiyono. Metode Penelitian Kuantitatif, Kualitatif dan R\&D. Bandung: Alfabeta. 2010. 